\title{
Response Factor in GC-FID Methyl Ester Analysis in Several Biodiesels: A Comparative Study of the EN 14103:2011 and ABNT 15764:2015 Methods versus a Proposed GC-FID Procedure for Individual Ester Determination
}

\author{
Willian L. G. da Silva, ${ }^{a}$ Arnaldo G. Oliveira Jr. ${ }^{a}$ and Matthieu Tubino ${ }^{\circledR * a}$ \\ Instituto de Química, Universidade de Campinas, P.O. Box 6154, 13830-970 Campinas-SP, Brazil
}

\begin{abstract}
A gas chromatography method with a flame ionization detector enabled by relative response factor was developed to determine the individual and the total content of esters in biodiesel. This method accounts for different response factors of the detector for a homologous series of esters that may be present in biodiesel. In this way, the determination of the total ester content of a reference sample $(100.5 \%)$ was done with more accuracy by the proposed procedure $(100.2 \%)$ than by official analytical methods: EN (74.68\%) and ABNT (118.2\%). Another advantage of the developed method is the possibility of determining individual ester concentrations, which provides information on several important biodiesel properties such as oxidative stability and cold flow properties. The mean absolute error in the determination of the individual ester content was ca. $1.1 \%$.
\end{abstract}

Keywords: biodiesel, ester content, method comparison, vegetable oils, individual ester determination

\section{Introduction}

Biodiesel is defined as mono-alkyl esters mixture of long chain fatty acids derived from the reaction of vegetable oils or animal fats and an alcohol in presence of a catalyst. ${ }^{1,2}$ It can be used as a green alternative to mineral diesel fuels for motors and heating systems. ${ }^{3-6}$ The main physical-chemical properties of this kind of fuel are highly dependent on a number of structural molecular factors like the number of double bonds in the fatty acid chain as well as the amount and position of allylic and bis-allylic carbons adjacent to the unsaturated ones. ${ }^{7}$

The chemical compositions of some potential oil sources for biodiesel production have been previously reviewed allowing a more realistic analysis of their feasibility as raw materials without compromising any of the fuel's properties. ${ }^{89}$ Some of them are so well behaved that it is possible to estimate some of the physical-chemical properties of the fuel, like iodine value, cetane number, and cold filter plugging point (CFPP), from their ester composition determined by chromatographic analysis. ${ }^{8,10}$ Serrano et al.,${ }^{11}$ for instance, reported that the amount of polyunsaturated esters in a biodiesel sample shows a good

*e-mail: tubino@unicamp.br

Editor handled this article: Eduardo Carasek correlation with the oxidative stability measured through its induction period (IP). Park et al. ${ }^{12}$ also showed that oxidation stability correlates to the polyunsaturated fraction (\% weigh) of the esters by a linear equation. Serrano et al. ${ }^{11}$ also demonstrated that the CFPP can be rationalized in terms of saturated short chain, saturated long chain and unsaturated fatty acids derivatives content. Therefore, knowing the ester content of a biodiesel or of its source allows to evaluate its properties, suitability and potential application as a biofuel.

Nowadays, there are two main standard analytical methods for the determination of fatty acid esters in biodiesel samples: the European Standard Test Methods EN 14103:2011 ${ }^{13}$ and the Brazilian National Standards Organization (Associação Brasileira de Normas Técnicas) ABNT 15764:2015, ${ }^{14}$ both of them relying on gas chromatography-flame ionization detector (GC-FID). The former is an internal standard method and the latter an external standard method. Both methods lack selectivity and accuracy in its determinations as they do not assume that each ester present in biodiesel has a different response in flame ionization detection (FID). Knowing the response (or correction) factor for each individual ester present in the sample is necessary in order to perform quantitative measurements of ester contents, because the detector's response for a homologous series is not constant, especially 
when unsaturated esters are present. The relative response factor (RRF) accounts for how many times the signal of the detector for a specific compound is more (or less) intense compared to an internal standard. For instance, a RRF equal to 2.0 means that the response of the detector for the compound is two times more intense than the response of the standard. This simple example illustrates how the presence of a component could be easily overestimated if the RRF is not taken into account. Certainly, in other cases the underestimation can occur.

Another negative aspect of these two methodologies is the inability to enable quantitative determination of each single ester in the sample, providing only the total ester content, which is not adequate for the estimation of properties that depends on chain length or saturation degree. ${ }^{15}$

For many years, there has been some effort to improve quantitative ester content determination by taking the differences of responses into account. Some of such studies had been developed even before biodiesel became widely used, due to the importance of ester determination related to vegetal oils. From the firsts examples ${ }^{16-18}$ published in the 80 's to the most recent developed methodologies for biodiesel analysis ${ }^{19-23}$ it is possible to realize the growing relevance of such matter. A very interesting article from Singh et al..$^{24}$ analyses the subject and shows how not taking into account the response factor differences could led to consider samples out of the EN 14103:2011 specification when they might actually be within it.

In this work, besides describing a CG-FID method for analysis of biodiesel samples considering the response factor of each individual ester in order to overcome the inaccuracies mentioned earlier, main problems with the current standard methods (ABNT NBR 15764:2015 and EN 14103:2011) were pointed. Comparative analyses of biodiesel samples from several different sources using ABNT NBR 15764:2015, EN 14103:2011 methods versus the procedure here proposed were performed. It was clearly demonstrated that not considering the response factor may affect the ester content determination in biodiesel samples.

\section{Experimental}

\section{Materials and standards}

Refined soybean, corn, babassu, canola, sunflower and linseed oils were purchased in the local market (Campinas, SP, Brazil). Macauba kernel and pulp oil were obtained from the "Associação de Pequenos Produtores Rurais de Riacho Dantas e Adjacências", Riacho Dantas, (Montes Claros, MG, Brazil). Palm kernel oil was obtained from Agropalma (Belém, PA, Brazil). Cotton oil was provided for Cargill
(Mairinque, SP, Brazil). Crude babassu oil was purchased from local suppliers in Teresina, PI, Brazil. Sulfuric acid and methanol (analytical grade) were purchased from Synth (Diadema, SP, Brazil). Sodium methoxide $(30 \% \mathrm{~m} / \mathrm{m}$ ) was obtained from Vetec (Duque de Caxias, RJ, Brazil). Amberlite ${ }^{\mathrm{TM}}$ BD10 dry resin was purchased from Dow Chemical (Shanghai, China). $n$-Hexane HPLC (high performance liquid chromatography) grade, methyl tridecanoate (purity $\geq 97 \%$ ) and methyl nonadecanoate were purchased from Sigma-Aldrich (St. Louis, MO, USA). The reference standard mixture of methyl esters of fatty acids with chain length varying between C8:0 and C24:0 was purchased from Supelco (Bellefonte, PA, USA).

\section{Biodiesel synthesis}

Biodiesel from several different sources were synthesized following procedures previously established in our laboratory for refined ${ }^{25}$ and unrefined ${ }^{26}$ oils.

\section{Gas chromatograph (GC-FID)}

Table 1 informs the conditions under which the chromatograph was used to perform the analyzes.

Table 1. Equipment conditions

\begin{tabular}{|c|c|}
\hline Gas chromatograph & $\begin{array}{c}\text { Agilent Technologies } 7890 \text { GC } \\
\text { System }\end{array}$ \\
\hline Inlet temperature $/{ }^{\circ} \mathrm{C}$ & 250 \\
\hline Column flow / $\left(\mathrm{mL} \mathrm{min}^{-1}\right)$ & 1 \\
\hline Split ratio & $1: 100$ \\
\hline Injection volume / $\mu \mathrm{L}$ & 1.0 \\
\hline Oven program initial temperature $/{ }^{\circ} \mathrm{C}$ & 60 \\
\hline Hold time $1 / \mathrm{min}$ & 2.0 \\
\hline $\operatorname{Ramp} 1 /\left({ }^{\circ} \mathrm{C} \min ^{-1}\right)$ & 16 \\
\hline Oven program temperature $2 /{ }^{\circ} \mathrm{C}$ & 200 \\
\hline Hold time 2 / min & 0 \\
\hline Ramp $2 /\left({ }^{\circ} \mathrm{C} \min ^{-1}\right)$ & 3 \\
\hline Oven program temperature $3 /{ }^{\circ} \mathrm{C}$ & 240 \\
\hline Hold time $3 / \mathrm{min}$ & 0 \\
\hline $\operatorname{Ramp} 3 /\left({ }^{\circ} \mathrm{C} \min ^{-1}\right)$ & 10 \\
\hline Oven program final temperature $/{ }^{\circ} \mathrm{C}$ & 250 \\
\hline Hold time $2 / \min$ & 1 \\
\hline Column & $\begin{array}{c}\text { Agilent DB-23 } \\
\text { (50\%-cyanopropyl)- } \\
\text { methylpolysiloxane } \\
30 \mathrm{~m} \times 250 \mu \mathrm{m} \times 0.25 \mu \mathrm{m}\end{array}$ \\
\hline Carrier gas & helium \\
\hline FID temperature $/{ }^{\circ} \mathrm{C}$ & 250 \\
\hline
\end{tabular}

FID: flame ionization detector. 


\section{EN 14103:2011 13}

Sampling, sample preparation, analysis and total ester content calculations were performed following the EN 14103:2011 procedure and the chromatographic conditions described in Table 1.

\section{ABNT NBR 15764:2015 14}

Sampling, sample preparation, analysis and total ester content calculations were performed following the ABNT NBR 15764:2015 procedure and the chromatographic conditions described in Table 1.

\section{Proposed method}

Two reference standard mixtures of methyl ester solutions in $n$-hexane were prepared ( 5 and $20 \mathrm{mg} \mathrm{L}^{-1}$ ) aiming the determination of each individual ester response factor. An aliquot of $800 \mu \mathrm{L}$ of methyl tridecanoate (internal standard) was added to both solutions.

Another reference standard mixture of methyl ester solution $\left(12.5 \mathrm{mg} \mathrm{L}^{-1}\right)$ with $800 \mu \mathrm{L}$ of methyl tridecanoate (internal standard) was prepared in order to validate the quantitative determination of the proposed method by comparison with the content values provided by the supplier. Biodiesel samples were prepared by adding $100 \mathrm{mg}$ of each biodiesel and $800 \mu \mathrm{L}$ of methyl tridecanoate (internal standard) to a $10 \mathrm{~mL}$ volumetric flask using $n$-hexane as solvent. Chromatographic determinations were performed in triplicate. Total and individual ester content calculations were performed accounting for the influence of response factor for each individual methyl ester and are described in detail in Results and Discussion section.

\section{Results and Discussion}

\section{ABNT NBR 15764:2015 and EN 14103:2011 methods- overview and critical analysis}

The European Standard EN 14103:2011 establishes a protocol for determining the content of fatty acid methyl esters and the content of linoleic acid derivatives (wt.\%) in biodiesel. A major disadvantage of this method is that it does not allow determination of the individual contents of the various esters in a biodiesel. This fact strongly limits the quantity of information that is obtained by this analytical procedure. This standard method is based on the chromatographic separation of esters which contain 6 to 24 carbons in the aliphatic chain and uses methyl nonadecanoate as internal standard. The peak assignment is achieved by comparing each retention time with those determined through chromatograms obtained with standards of the individual esters. The ester content is calculated from the sum of the areas of the esters' intrinsic peaks. This total area $(\Sigma \mathrm{A})$ is compared with the area of the standard with a known concentration which leads to the total ester content (C), as shown in equation 1 .

$\mathrm{C}(\%)=\left(\left(\Sigma \mathrm{A}-\mathrm{A}_{\mathrm{IS}}\right) \times \mathrm{m}_{\mathrm{IS}} \times 100\right) /\left(\mathrm{A}_{\mathrm{IS}} \times \mathrm{m}_{\text {sample }}\right)$

$\Sigma \mathrm{A}$ and $\mathrm{A}_{\mathrm{IS}}$ are the summations of the areas of the peaks in the chromatogram which correspond to the methyl esters and the internal standard peaks, respectively, $\mathrm{m}_{\mathrm{IS}}$ is the mass of the internal standard, and $\mathrm{m}_{\text {sample }}$ is the mass of the sample.

Although this standard test method is a widely used tool for determining the total amount of methyl esters, FID lacks selectivity in complex samples. This restricts the analysis to a mere comparison of retention times with the commercially available standards, reducing reliability. ${ }^{24,27}$ Also, in EN 14103:2011 calculations, the response factor is considered equal to 1.0 for all esters, implying a possible error in the estimation of their contents. For example, it is reasonable to assume that the linolenic ester content determined by this method carries some inaccuracy due to its unsaturated chain. Considering the importance of this parameter in the evaluation of the oxidative stability of biodiesel, this limitation of the method demands a new approach. $^{28}$

The ABNT NBR 15764:2015 method establishes a protocol for the determination of fatty acid methyl ester content using an external standard. For biodiesel samples containing mostly the 18-carbon fatty ester chain, methyl octadecanoate is employed as standard. In the cases of samples containing an expressive amount of fatty acids with less than 14 carbon fatty ester chains, the use of methyl dodecanoate is recommended. These two standards must be used in different concentrations in order to build the analytical curves. Peak assignment is supported by a collection of attached chromatograms comprising bovine fat, coconut, soy, rapeseed, and palm oil biodiesels. Moreover, the use of mass spectrometry (MS) to confirm the assignments is recommended.

The ABNT NBR 15764:2015 method also does not take into account possible inaccuracies that differences in the response factor (RF) may cause. However, using the two different external standards cited above, according to the length of the ester carbon chain, partially accounts for these differences. Notwithstanding, the effect of unsaturated chains in the response factor is still neglected. Additional disadvantages of this method include: $(i)$ it is 
necessary to use two analytical curves, depending on the nature of the oil source, each of them comprising at least six solutions in different concentrations of the standards; (ii) an increased possibility of injection errors which the procedure may cause. ${ }^{29-31}$ Table 2 shows a comparison of the main characteristics between the two standard test methods mentioned above.

Table 2. Comparison between EN 14103:2011 and ABNT 15764:2015 standard test methods for the determination of fatty acid methyl ester content in biodiesel samples

\begin{tabular}{|c|c|c|}
\hline & EN 14103:2011 13 & ABNT $15764: 2015^{14}$ \\
\hline Detector & FID & FID \\
\hline Standard used & internal standard & external standard \\
\hline Standard & methyl nonadecanoate & $\begin{array}{l}\text { methyl dodecanoate } \\
\text { and methyl } \\
\text { octadecanoate }\end{array}$ \\
\hline Fatty ester chain length & 6 to 24 carbon atoms & 6 to 26 carbon atoms \\
\hline $\begin{array}{l}\text { Accounts for detector's } \\
\text { response factor? }\end{array}$ & no & to a limited degree \\
\hline $\begin{array}{l}\text { Single ester } \\
\text { determination }\end{array}$ & only C18:3 & no \\
\hline
\end{tabular}

FID: flame ionization detection.

Both standard methods discussed above rely on the use of a flame ionization detector (FID). This detector is the most widely used for GC. In this kind of device, the eluent from the chromatographic column is introduced directly into an air-hydrogen flame. From this combustion, the organic molecules produce ions that are detected and quantified by differences in the electric current generated in the detector. Despite the fact that the mechanisms of ionization that occur inside the flame are not fully understood, it is known, however, that the number of ions produced is roughly proportional to the number of reduced carbon atoms in the flame. Functional groups like carbonyl, alcohol, halogen, and amine yield fewer ions or none at all in a flame. ${ }^{32}$ Due to this fact, FID is ideal for the chromatographic analysis of hydrocarbons, but using this kind of detector for other organic compounds may give rise to differences in the response. Such kind of effect can occur, especially when a standard compound (internal or external) is used which does not have exactly the same chemical structure of the analyte. Since biodiesel contains a wide variety of esters with different degrees of unsaturation in its alkyl chain, measurements of the content of an ester, by mere comparison of the areas with one single standard, may conduct to inaccurate result. A simple way to solve this limitation is to consider a response factor relative to each one of the analytes with respect to an internal standard in order to correct the responses of the detector.
Determination of the response factor (RF) and of the relative response factor (RRF) by the proposed method

The response factor $(\mathrm{RF})$ for each single methyl ester (RFX) was determined according to equation 2 .

$\mathrm{RF}_{\mathrm{X}}=\mathrm{A}_{\mathrm{X}} / \mathrm{C}_{\mathrm{X}}$

where $A_{X}$ is the ester peak area of the sample signal, and $\mathrm{C}_{\mathrm{X}}$ is the concentration of the $\mathrm{X}$-ester (or of the internal standard) in $\mathrm{mg} \mathrm{mL}^{-1}$.

The experimental RF obtained for the internal standard was taken as reference. The choice of a new internal standard (methyl tridecanoate-C13:0) consisted of an attempt to avoid the part of the chromatogram which is too highly populated by signals originated by the methyl esters present in the sample. Since it is not naturally present in biodiesel, it reduces the chance of peak overlap. It is also less expensive when compared to the other esters.

From the obtained RF values, the relative response factor (RRF) with respect to the internal standard response factor $\left(\mathrm{RF}_{\mathrm{IS}}\right)$ was calculated for each ester relative to the internal standard by using equation 3 .

$\mathrm{RRF}_{\mathrm{X}}=\mathrm{RF}_{\mathrm{X}} / \mathrm{RF}_{\mathrm{IS}}$

Then, the amount in mass percentage of each methyl ester (ME\%) was determined by equation 4 .

$\operatorname{ME}(\%)=\left(\mathrm{Ax} \times \mathrm{C}_{\mathrm{IS}} \times \mathrm{V} \times 100\right) /\left(\mathrm{A}_{\mathrm{IS}} \times \mathrm{m} \times \mathrm{RRFx}\right)$

where $A_{x}$ is the area of the sample signal, $C_{I S}$ is the concentration $\left(\mathrm{mg} \mathrm{mL}^{-1}\right)$ of the internal standard, $\mathrm{V}$ is the volume $(\mathrm{mL})$ of the sample, $\mathrm{A}_{\mathrm{IS}}$ is the area of the internal standard signal, and $\mathrm{m}$ is the mass (in milligrams) of the biodiesel sample.

The RRF values calculated for some methyl esters are shown in Table 3. It can be observed that the response factors are comparable to that of the standard C13:0 (taken as 1.00) only in the cases where the number of carbons in the saturated molecules chains of the samples are close to the number of carbons in the molecules of the standard, like C14:0 and C12:0. By carefully observing the RRF values in Table 3 for a homologous series of saturated alkyl chain lengths, one can see a tendency of the response factor to increase as the number of carbons increases. The only exception is eicosanoic (arachidic) acid (C20:0), which presented the second lowest value of RF, as can be observed in Figure 1. The reasons for this unexpected behavior are still unknown.

Similarly, considering the C18:n carbon chains (with $n$ varying from 0 to 3 ), the increase in the number of double 
bonds in $\mathrm{C} 18$ leads to a respective increase in the RRF values, as shown in Table 3 and also in Figure 2.

Table 3. Response factor (RRF) for each individual methyl ester

\begin{tabular}{lc}
\hline Ester & $\mathrm{RRF}_{\text {average }}$ \\
\hline $\mathrm{C} 8: 0$ & $0.59 \pm 0.06$ \\
$\mathrm{C} 10: 0$ & $0.75 \pm 0.08$ \\
$\mathrm{C} 12: 0$ & $0.90 \pm 0.08$ \\
$\mathrm{C} 14: 0$ & $1.01 \pm 0.08$ \\
$\mathrm{C} 16: 0$ & $1.21 \pm 0.01$ \\
$\mathrm{C} 16: 1$ & $1.12 \pm 0.08$ \\
$\mathrm{C} 18: 0$ & $1.21 \pm 0.08$ \\
$\mathrm{C} 18: 1$ & $1.5 \pm 0.3$ \\
$\mathrm{C} 18: 2$ & $1.5 \pm 0.3$ \\
$\mathrm{C} 18: 3$ & $2.1 \pm 0.2$ \\
$\mathrm{C} 20: 0$ & $0.71 \pm 0.04$ \\
$\mathrm{C} 22: 0$ & $1.3 \pm 0.1$ \\
$\mathrm{C} 22: 1$ & $1.27 \pm 0.08$ \\
$\mathrm{C} 24: 0$ & $1.4 \pm 0.1$ \\
\hline
\end{tabular}

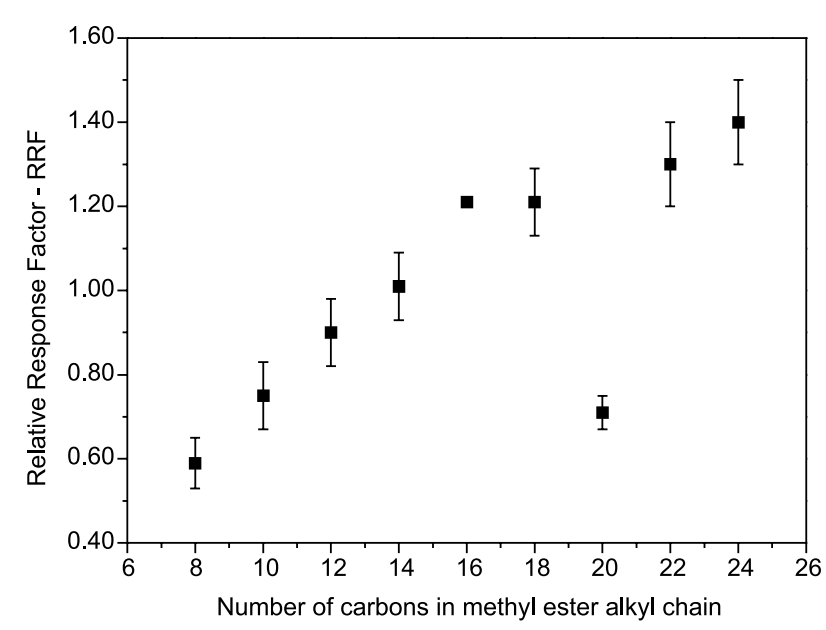

Figure 1. Relative response factor (RRF) for saturated alkyl chain methyl esters versus the number of carbon atoms in the molecular chain.

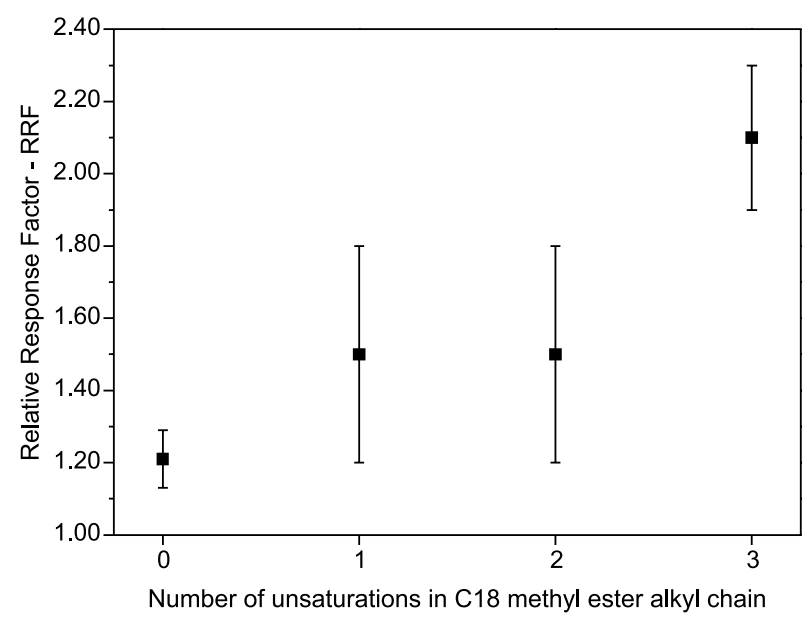

Figure 2. Relative response factor (RRF) for C18:0, C18:1, C18:2 and C18:3 methyl esters.
Determination of the concentration of the methyl esters in a standard solution

In order to test the proposed method using the calculated RRF values, the content of each single ester (from $\mathrm{C} 8$ to $\mathrm{C} 24$ ) present in a certified standard mixture of methyl esters was determined. The ester concentrations which had been reported by the provider were assumed to be the real values. Table 4 compares the reference values of the standard mixture of methyl esters with those obtained by the proposed analytical procedure. The relative error is also reported. It can be noted that the obtained values are close to the real ones, with the modular value of the relative error varying from a minimum of $0.1 \%$ to a maximum of $3.8 \%$.

Table 4. Concentration of each individual ester in a certificated sample assumed to be the real value; individual ester content determined by the proposed method; the calculated error of the analysis relative to the real values (relative error)

\begin{tabular}{lccc}
\hline Ester & $\begin{array}{c}\text { Real value / } \\
(\% \mathrm{~m} / \mathrm{m})\end{array}$ & $\mathrm{C} /(\% \mathrm{~m} / \mathrm{m})$ & $\begin{array}{c}\text { Relative } \\
\text { error } / \%\end{array}$ \\
\hline C8:0 & 8.3 & 8.29 & -0.1 \\
C10:0 & 8.0 & 8.01 & 0.1 \\
C12:0 & 8.0 & 8.08 & 1.0 \\
C14:0 & 8.0 & 8.03 & 0.4 \\
C16:0 & 11.4 & 11.04 & -3.1 \\
C16:1 & 4.9 & 4.87 & -0.6 \\
C18:0 & 8.0 & 7.94 & -0.7 \\
C18:1 & 5.0 & 5.19 & 3.8 \\
C18:2 & 5.0 & 5.11 & -2.2 \\
C18:3 & 5.0 & 4.98 & -0.4 \\
C20:0 & 8.0 & 7.88 & -1.5 \\
C22:0 & 7.9 & 7.83 & -0.9 \\
C22:1 & 5.0 & 5.00 & 0.0 \\
C24:0 & 8.0 & 7.96 & -0.5 \\
\hline Total & 100.5 & 100.2 & -0.3 \\
\hline
\end{tabular}

Determination of the content of the individual methyl esters in biodiesel samples

In order to apply the proposed method in real biodiesel samples, eleven biodiesels were prepared from seven different refined (soybean, corn, canola, linseed, babassu, sunflower, palm kernel) and four unrefined (babassu, macauba kernel, macauba pulp, cotton) oil sources. All these biodiesels were analyzed by the proposed GC-FID procedure accounting for differences in the response factors.

Table 5 shows the obtained results and compares them with the ranges of concentrations reported in the literature for each respective oil source. As it can be noted a complete concordance was observed. 
Table 5. Individual methyl ester content in biodiesel samples obtained by the proposed GC-FID method and reference values from literature ${ }^{33,34}$

\begin{tabular}{|c|c|c|c|c|c|c|c|c|c|c|c|c|}
\hline Ester & Soybean & $\begin{array}{c}\text { Reference } \\
\text { value }^{33}\end{array}$ & Canola & $\begin{array}{c}\text { Reference } \\
\text { value }^{33}\end{array}$ & Sunflower & Reference value $e^{33}$ & Palm kernel & $\begin{array}{c}\text { Reference } \\
\text { value }^{33}\end{array}$ & Corn & $\begin{array}{c}\text { Reference } \\
\text { value }^{33}\end{array}$ & Cotton & $\begin{array}{c}\text { Reference } \\
\text { value }^{33}\end{array}$ \\
\hline $\mathrm{C} 8: 0 /(\% \mathrm{~m} / \mathrm{m})$ & & & & & & & $4.07 \pm(0.02)$ & $1.9-6.2$ & & & & \\
\hline $\mathrm{C} 10: 0 /(\% \mathrm{~m} / \mathrm{m})$ & & & & & & & $3.53 \pm(0.01)$ & $2.6-5.0$ & & & & \\
\hline $\mathrm{C} 12: 0 /(\% \mathrm{~m} / \mathrm{m})$ & & $0-0.1$ & & & & $0-0.1$ & $48.23 \pm(0.06)$ & $40-55$ & & $0-0.3$ & & $0-0.2$ \\
\hline $\mathrm{C} 14: 0 /(\% \mathrm{~m} / \mathrm{m})$ & & $0-0.2$ & & $0-0.2$ & & $0-0.2$ & $16.65 \pm(0.03)$ & $14-18$ & & $0-0.3$ & & $0.6-1.0$ \\
\hline $\mathrm{C} 16: 0 /(\% \mathrm{~m} / \mathrm{m})$ & $13.42 \pm(0.01)$ & $9.7-13.3$ & $6.67 \pm(0.02)$ & $3.3-6.0$ & $5.84 \pm(0.01)$ & $5-8$ & $9.03 \pm(0.02)$ & $6.5-10.3$ & $14.75 \pm(0.01)$ & $9.2-16.5$ & $29.91 \pm(0.06)$ & $18.1-26.4$ \\
\hline $\mathrm{C} 16: 1 /(\% \mathrm{~m} / \mathrm{m})$ & 0.00 & $0-0.2$ & 0.00 & $0.1-0.6$ & 0.00 & $0-0.3$ & 0.00 & & 0.00 & $0-0.4$ & 0.00 & $0-0.7$ \\
\hline $\mathrm{C} 18: 0 /(\% \mathrm{~m} / \mathrm{m})$ & $3.99 \pm(0.01)$ & $3.0-5.4$ & $4.09 \pm(0.01)$ & $1.1-2.5$ & $4.52 \pm(0.01)$ & $2.5-7.0$ & $2.39 \pm(0.01)$ & $1.3-3$ & $2.97 \pm(0.01)$ & $0-3.3$ & $3.36 \pm(0.005)$ & $2.1-3.3$ \\
\hline $\mathrm{C} 18: 1 /(\% \mathrm{~m} / \mathrm{m})$ & $27.09 \pm(0.01)$ & $17.7-28.5$ & $65.45 \pm(0.23)$ & $52-67$ & $41.53 \pm(0.12)$ & $13-40$ & $13.93 \pm(0.05)$ & $12-21$ & $35.38 \pm(0.02)$ & $20-42.2$ & $16.22 \pm(0.01)$ & $14.2-21.7$ \\
\hline $\mathrm{C} 18: 2 /(\% \mathrm{~m} / \mathrm{m})$ & $51.28 \pm(0.02)$ & $49.8-57.1$ & $22.96 \pm(0.08)$ & $16-25$ & $47.12 \pm(0.14)$ & $48-74$ & $2.15 \pm(0.01)$ & $1-3.5$ & $46.22 \pm(0.04)$ & $39.4-65.6$ & $50.51 \pm(0.04)$ & $55.6-61.6$ \\
\hline $\mathrm{C} 18: 3 /(\% \mathrm{~m} / \mathrm{m})$ & $4.22 \pm(0.01)$ & $5.5-9.5$ & $0.82 \pm(0.003)$ & $6-14$ & & $0-0.3$ & & $0-0.7$ & $0.68 \pm(0.01)$ & $0.5-1.5$ & & $0-0.4$ \\
\hline $\mathrm{C} 20: 0 /(\% \mathrm{~m} / \mathrm{m})$ & & $0.1-0.6$ & & $0.2-0.8$ & & $0.2-0.5$ & & $0-0.3$ & & $0.3-0.7$ & & $0.2-0.5$ \\
\hline $\mathrm{C} 22: 0 /(\% \mathrm{~m} / \mathrm{m})$ & & $0.3-0.7$ & & $0-0.5$ & $0.99 \pm(0.01)$ & $0.5-1.3$ & & & & $0-0.5$ & & $0-0.6$ \\
\hline $\mathrm{C} 22: 1 /(\% \mathrm{~m} / \mathrm{m})$ & & $0-0.3$ & & $0-4.7$ & & $0-0.5$ & & & & $0-0.1$ & & $0-0.3$ \\
\hline $\mathrm{C} 24: 0 /(\% \mathrm{~m} / \mathrm{m})$ & & $0-0.4$ & & $0-0.2$ & & $0-0.4$ & & & & $0-0.4$ & & $0-0.1$ \\
\hline Ester & $\begin{array}{c}\text { Macauba } \\
\text { kernel }\end{array}$ & $\begin{array}{c}\text { Reference } \\
\text { value }^{34}\end{array}$ & $\begin{array}{c}\text { Macauba } \\
\text { pulp }\end{array}$ & $\begin{array}{c}\text { Reference } \\
\text { value }^{34}\end{array}$ & $\begin{array}{c}\text { Crude } \\
\text { babassu oil }\end{array}$ & $\begin{array}{c}\text { Refined } \\
\text { babassu oil }\end{array}$ & $\begin{array}{c}\text { Reference } \\
\text { value }^{34}\end{array}$ & Linseed & $\begin{array}{c}\text { Reference } \\
\text { value }^{34}\end{array}$ & & & \\
\hline $\mathrm{C} 8: 0 /(\% \mathrm{~m} / \mathrm{m})$ & $7.11 \pm(0.09)$ & 6.2 & & & $6.00 \pm(0.02)$ & $6.67 \pm(0.04)$ & $2.6-7.3$ & & & & & \\
\hline $\mathrm{C} 10: 0 /(\% \mathrm{~m} / \mathrm{m})$ & $4.71 \pm(0.05)$ & 5.3 & & & $4.97 \pm(0.02)$ & $4.98 \pm(0.03)$ & $1.2-7.6$ & & & & & \\
\hline $\mathrm{C} 12: 0 /(\% \mathrm{~m} / \mathrm{m})$ & $40.06 \pm(0.08)$ & 43.6 & & & $43.81 \pm(0.05)$ & $48.59 \pm(0.07)$ & $40-55$ & & & & & \\
\hline $\mathrm{C} 14: 0 /(\% \mathrm{~m} / \mathrm{m})$ & $10.91 \pm(0.01)$ & 8.5 & & & $17.17 \pm(0.06)$ & $18.42 \pm(0.01)$ & $11-27$ & & & & & \\
\hline $\mathrm{C} 16: 0 /(\% \mathrm{~m} / \mathrm{m})$ & $8.30 \pm(0.02)$ & 5.3 & $21.16 \pm(0.06)$ & 18.70 & $9.22 \pm(0.01)$ & $8.73 \pm(0.02)$ & $5.2-11$ & $4.52 \pm(0.01)$ & $5.6-7$ & & & \\
\hline $\mathrm{C} 16: 1 /(\% \mathrm{~m} / \mathrm{m})$ & 0.00 & 2.4 & $3.58 \pm(0.01)$ & 4.00 & 0.00 & 0.00 & & 0.00 & & & & \\
\hline $\mathrm{C} 18: 0 /(\% \mathrm{~m} / \mathrm{m})$ & $3.87 \pm(0.01)$ & & $2.57 \pm(0.006)$ & 2.80 & $3.40 \pm(0.009)$ & $2.54 \pm(0.01)$ & $1.8-7.4$ & $3.38 \pm(0.01)$ & $3-4$ & & & \\
\hline $\mathrm{C} 18: 1 /(\% \mathrm{~m} / \mathrm{m})$ & $22.30 \pm(0.05)$ & 25.5 & $57.51 \pm(0.16)$ & 53.40 & $13.24 \pm(0.03)$ & $8.96 \pm(0.03)$ & 9.20 & $20.82 \pm(0.39)$ & $17.7-20.3$ & & & \\
\hline $\mathrm{C} 18: 2 /(\% \mathrm{~m} / \mathrm{m})$ & $2.75 \pm(0.01)$ & 3.3 & $13.43 \pm(0.04)$ & 3.30 & $2.21 \pm(0.01)$ & $1.11 \pm(0.01)$ & $1.4-6.6$ & $13.24 \pm(0.05)$ & 15.7 & & & \\
\hline $\mathrm{C} 18: 3 /(\% \mathrm{~m} / \mathrm{m})$ & & & & & & & & $58.04 \pm(0.21)$ & $52-57.8$ & & & \\
\hline $\mathrm{C} 20: 0 /(\% \mathrm{~m} / \mathrm{m})$ & & & $1.76 \pm(0.005)$ & & & & & & $0-0.1$ & & & \\
\hline \multicolumn{13}{|l|}{$\mathrm{C} 22: 0 /(\% \mathrm{~m} / \mathrm{m})$} \\
\hline \multicolumn{13}{|l|}{$\mathrm{C} 22: 1 /(\% \mathrm{~m} / \mathrm{m})$} \\
\hline $\mathrm{C} 24: 0 /(\% \mathrm{~m} / \mathrm{m})$ & & & & & & & & & & & & \\
\hline
\end{tabular}

Table 6. Total ester content for biodiesel samples and for the standard solution determined by the three different methods, i.e., the proposed method, the EN 14103:2011 and the ABNT 15764

\begin{tabular}{|c|c|c|c|}
\hline \multirow{2}{*}{ Biodiesel } & \multicolumn{3}{|c|}{ Total ester content $/(\% \mathrm{~m} / \mathrm{m})$} \\
\hline & Proposed method & EN 14103:2011 & ABNT 15764 \\
\hline Soybean & $68.35 \pm 0.03$ & $81.85 \pm 0.04$ & $95 \pm 1$ \\
\hline Canola & $63.7 \pm 0.4$ & $92.85 \pm 0.08$ & $84.7 \pm 0.5$ \\
\hline Corn & $71.4 \pm 0.1$ & $77.46 \pm 0.08$ & $86.5 \pm 0.3$ \\
\hline Sunflower & $73.1 \pm 0.4$ & $80.33 \pm 0.09$ & $89 \pm 1$ \\
\hline Macauba pulp & $68.3 \pm 0.4$ & $75.53 \pm 0.01$ & $96 \pm 2$ \\
\hline Macauba kernel & $87.13 \pm 0.07$ & $72.2 \pm 0.2$ & $97.0 \pm 0.2$ \\
\hline Palm kernel & $89.62 \pm 0.02$ & $69.9 \pm 0.3$ & $95.6 \pm 0.2$ \\
\hline Crude babassu & $83.13 \pm 0.03$ & $65.3 \pm 0.2$ & $90.8 \pm 0.2$ \\
\hline Refined babassu & $81.60 \pm 0.06$ & $62.40 \pm 0.3$ & $79.1 \pm 0.1$ \\
\hline Cotton & $66.4 \pm 0.1$ & $73.3 \pm 0.1$ & $89.7 \pm 0.5$ \\
\hline Linseed & $99.5 \pm 0.6$ & $94.6 \pm 0.5$ & $91 \pm 1$ \\
\hline $\begin{array}{l}\text { Methyl ester standard solution } \\
\text { reference value } 100.5 \pm 0.8\end{array}$ & $100.2 \pm 0.1$ & $74.68 \pm 0.04$ & $118.2 \pm 0.9$ \\
\hline
\end{tabular}

Finally, a comparison was performed among the method here proposed and the EN 14103:2011 and ABNT NBR 15764:2015 test methods for determining the total ester content in the biodiesel samples (Table 6). This table shows a comparison of the values obtained by the different methods for all the eleven analyzed biodiesels. It is clear that using the method proposed here, and therefore accounting for the differences in response factors of each single ester, the obtained value of the total ester content $(100.2 \%)$ is much closer to the reference sample $(100.5 \%)$ than those obtained by the analytical method EN 14103:2011 (74.68\%) and by the ABNT NBR 15764:2015 (118.2\%). The higher 
Table 7. Statistical data used in Dunnett's method analysis for ABNT 15764:2015, EN 14103:2011, our proposed method and reference sample

\begin{tabular}{lcccc}
\hline Method/sample & Number of replicates & Mean / $\%$ & Standard deviation (SD) & Grouping $^{\mathrm{a}}$ \\
\hline ABNT 15764:2015 & 3 & 118.2 & 0.9 & \\
EN 14103:2011 & 3 & 74.68 & 0.04 & $\mathrm{~A}$ \\
Proposed method & 3 & 100.2 & 0.1 & $\mathrm{~A}$ \\
Reference (control) & 3 & 100.5 & 0.8 & \\
\hline
\end{tabular}

aeans not labelled with the letter A are significantly different from the control level mean.

relative error values observed between the reference value and the results obtained by the EN 14103:2011 and by the ABNT NBR 15764:2015 methods can be rationalized as a consequence of the direct comparison of the areas of the chromatographic peaks for the calculation of the individual composition of all esters present in the biodiesels as if they all have the same response factor to the FID.

The suitability of the proposed method was statistically evaluated by Dunnett's method using Minitab ${ }^{\circledR}$ software..$^{35}$ This method consists in using ANOVA (analysis of variance) to create confidence intervals for differences between the mean of each studied method and the mean of the reference standard. If zero (represented by the dashed line) belongs to the range of a comparison interval there is no significant difference between the two means (methods) under comparison. As depicted in Figure 3 and shown in Table 7 , the only method among those studied that match this requirement is that proposed in this paper.

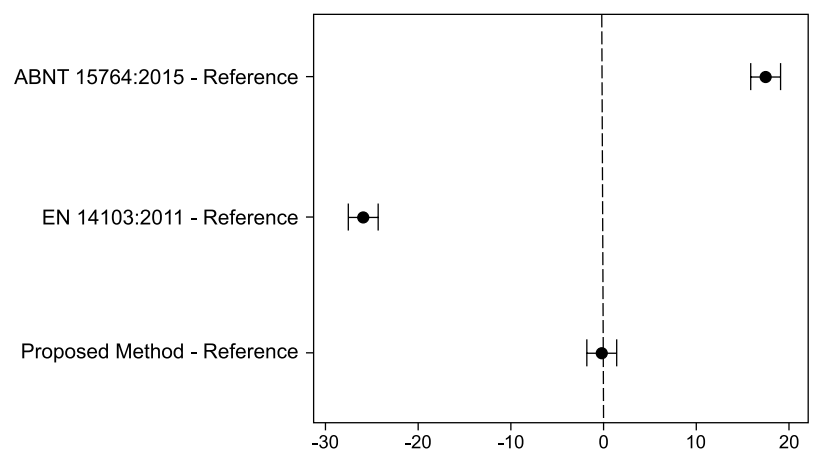

Figure 3. Dunnett simultaneous comparison test $(\alpha=0.05)$ for the studied methods (ABNT 15764:2015; EN 14103:2011; proposed method) and for the reference sample.

\section{About EN 14103:2020}

Recently, EN 14103:2011 was updated by the European Committee of Standardization (CEN): EN 14103:2020. ${ }^{36}$ The previous version was superseded, and some technical modifications were introduced, like including changes in calculations of results which now incorporate theoretical flame ionization detector correction factor (TCF). As the document states, this gives a better accuracy of the calculated contents in case of presence of methyl esters with short chains. This fact only contributes to our statement that methods in which response factor is not taken into consideration are not as accurate as those which include RF in its calculations. Although this change represents a major improvement of EN 14103 accuracy, other test methods (e.g., ABNT 15764:2015) still carry some degree of inaccuracy.

\section{Conclusions}

The chromatographic method presented in this work accounts for the differences observed in the FID signal related to each methyl ester in the biodiesel samples by including RRF with respect to intrinsic internal standards.

This approach allows a more accurate determination of the concentration of each ester and consequently, the total ester content determination in biodiesel samples with accuracy.

By using this approach, was determined, with acceptable relative error, each individual ester content in a standard reference sample. This is an important advantage of the proposed method, over the officials (EN 14103:2011 and ABNT NBR 15764:2015) methods with which it is not possible to quantify each single methyl ester contained in biodiesel.

With respect to the total methyl ester content, it was performed the analysis of a certified reference material using the proposed method. The obtained results showed better agreement with the real values than those obtained by the EN 14103:2011 and ABNT NBR 15764:2015 test methods, fact confirmed through statistical analysis using the reference material information provided by the fabricant as real value. This better agreement evidences the importance of considering the different responses of each ester by the flame ionization detection. Since many physical-chemical properties of biodiesels (i.e., oxidative stability, cold filter plugging point, iodine value, etc.) can be rationalized and even predicted from the ester contents of the biodiesel, the inclusion of a response factor ensures more accurate determination of the composition profile of the fuel and can provide a better preview of such properties.

Finally, considering the influence of the relative response factor of each ester, a variety of biodiesel samples 
were analyzed providing accurate information of the total and individual ester content for a number oil sources, including some promising but not yet widely studied sources. The data presented here can be helpful to guide further studies on synthesis, blending and determination of physical chemical properties of biodiesels derived from oils sources with scarce information published.

\section{Acknowledgments}

The authors are grateful to CNPq (420868/2016-0, 404808/2013-1 and 304605/2016-6) for financial support.

\section{References}

1. Demirbas, A.; Energy Convers. Manage. 2003, 44, 2003.

2. Lôbo, I. P.; Ferreira, S. L. C.; Quim. Nova 2009, 32, 1596.

3. Atabani, A. E.; Silitonga, A. S.; Badruddin, I. A.; Mahlia, T. M. I.; Masjuki, H. H.; Mekhilef, S.; Renewable Sustainable Energy Rev .2012, 16, 2070.

4. Schuchardt, U.; Sercheli, R.; Vargas, R. M.; J. Braz. Chem. Soc. 2008, 9, 199.

5. Leung, D. Y. C.; Koo, B. C. P.; Guo, Y.; Bioresour. Technol. 2006, 97,250

6. Knothe, G.; J. Am. Oil Chem. Soc. 2006, 10, 83.

7. Joshi, G.; Lamba, B. Y.; Rawat, D. S.; Mallick, S.; Murthy, K. S. R.; Ind. Eng. Chem. Res. 2013, 52, 7586.

8. Dabdoub, M. J.; Bronzel, J. L.; Quim. Nova 2009, 32, 776.

9. Hass, M. J.; McAloon, A. J.; Yee, W. J.; Foglia, T. A.; Bioresour. Technol. 2006, 97, 671.

10. Demirbas, A.; Fuel 2008, 87, 1743.

11. Serrano, M.; Oliveros, R.; Sánchez, M.; Moraschini, A.; Martínez, M.; Aracil, J.; Energy 2014, 65, 109.

12. Park, J. Y.; Kim, D. K.; Lee, J. P.; Park, S. C.; Kim, Y. J.; Lee, J. S.; Bioresour. Technol. 2008, 99, 1196.

13. EN 14103:2011: Fat and Oil Derivatives-Fatty Acid Methyl Esters (FAME) - Determination of Ester and Linolenic Acid Methyl Ester Contents; European Committee for Standardization, Brussels, 2011, available at https://www. en-standard.eu/din-en-14103-fat-and-oil-derivatives-fatty-acidmethyl-esters-fame-determination-of-ester-and-linolenic-acidmethyl-ester-contents/, accessed in October 2021.

14. ABNT NBR 15764:2015: Biodiesel - Determinação do Teor de Ésteres por Cromatografia Gasosa, $4^{\text {th }}$ ed.; Associação Brasileira de Normas Técnicas: Rio de Janeiro, 2015, available at https://www.normas.com.br/visualizar/abnt-nbr-nm/28879/ abnt-nbr15764-biodiesel-determinacao-do-teor-total-deesteres-por-cromatografia-gasosa, accessed in October 2021.

15. Visentainer, J. V.; Quim. Nova 2012, 35, 274.

16. Bannon, C. D.; Craske, J. D.; Hilliker, A. E.; J. Am. Oil Chem. Soc. 1986, 63, 105.
17. Craske, J. D.; Bannon, C. D.; J. Am. Oil Chem. Soc. 1987, 64, 1413.

18. Badings, H. T.; de Jong, C.; J. Am. Oil Chem. Soc. 1988, 65, 659.

19. Seeley, J. V.; Seeley, S. K.; Anal. Chem. 2013, 85, 557.

20. Sato, R. T.; Stroppa, P. H. F.; Silva, A. D.; Oliveira, M. A. L.; Quim. Nova 2016, 39, 352.

21. Marques, M. V.; Naciuk, F. F.; Mello, A. A. S.; Seibel, N. M.; Fontoura, L. A. M.; Quim. Nova 2010, 33, 978.

22. Faria, F. D.; Cerqueira, K. O.; Leal G. P.; Pereira, R. C. L.; Neto, M. J. R. G.; J. ASTM Int. 2010, 7, ID JAI102556.

23. Silva, F. L.; Melo, L. N.; Wolf, C. R.; Meneghetti, S. M. P.; Bortoluzzi, J. H.; J. Braz. Chem. Soc. 2018, 29, 1336.

24. Singh, D.; Chopra, A.; Kumar, R.; Sastry, M. I. S.; Patel, M. B.; Basu, B.; Chromatographia 2014, 77, 165.

25. da Silva, W. L. G.; de Souza, P. T.; Shimamoto, G. G.; Tubino, M.; J. Braz. Chem. Soc. 2015, 26, 1745.

26. da Silva, W. L. G.; Salomão, A. A.; de Souza, P. T.; Ansolin, M.; Tubino, M.; J. Braz. Chem. Soc. 2018, 29, 240.

27. Dodds, E. D.; McCoy, M. R.; Rea, L. D.; Kennish, J. M.; Lipids 2005, 40, 419.

28. Borsato, D.; Cini, J. R. M.; Silva, H. C.; Coppo, R. L.; Angilelli, K. G.; Moreira, I.; Maia, E. C. R.; Fuel Process. Technol. 2014, 127, 111.

29. Collins, C. H.; Braga, G. L.; Bonato, P. S.; Fundamentos de Cromatografia, $1^{\text {st }}$ ed.; Editora da UNICAMP: Campinas, Brazil, 2006.

30. Grob, R. L.; Barry, E. F.; Modern Practice of Gas Chromatography, $4^{\text {th }}$ ed.; Wiley-Interscience: New Jersey, USA, 2004.

31. Harris, D. C.; Análise Química Quantitativa, $8^{\text {th }}$ ed.; LTC editora: Rio de Janeiro, Brazil, 2012.

32. Skoog, D. A.; Holler, F. J.; Crouch, S. R.; Principles of Instrumental Analysis, $7^{\text {th }}$ ed.; Cengage Learning: Boston, USA, 2016.

33. Firestone, D.; Physical and Chemical Characteristics of Oils, Fats, and Waxes, $2^{\text {nd }}$ ed.; FDA: Washington DC, USA, 2006.

34. Martins, H.; Teixeira, L. C.; Oliveira, A. M.; Produção de Combustíveis Líquidos a Partir de Óleos Vegetais: Relatório Técnico Final, vol. 2; CETEC: Belo Horizonte, 1983, p. 18.

35. Minitab ${ }^{\circledR}$, v. 17; Minitab Inc.; State College, PA, USA, 2010.

36. EN 14103:2020: Fat and Oil Derivatives-Fatty Acid Methyl Esters (FAME) - Determination of Ester and Linolenic Acid Methyl Ester Contents; European Committee for Standardization, Brussels, 2020, available at https://www.enstandard.eu/une-en-14103-2020-fat-and-oil-derivatives-fattyacid-methyl-esters-fame-determination-of-ester-and-linolenicacid-methyl-ester-contents/, accessed in October 2021.

Submitted: July 19, 2021

Published online: October 26, 2021 